\title{
Adoption of B2B e-Commerce in Developing Countries: Evidence from Ready Made Garment (RMG) Industry in Bangladesh
}

\author{
Md. Rakibul Hoque \\ Department of Management Information Systems \\ University of Dhaka,Bangladesh \\ rakibul@du.ac.bd \\ Richard Boateng* \\ Department of Operations and Management Information Systems \\ University of Ghana, Ghana \\ richboateng@ug.edu.gh
}

\begin{abstract}
The rapid adoption of e-Commerce, especially Business-to-Business (B2B) e-Commerce among Ready-made Garments (RMG) industry is a key opportunity for local and international trade development of developing countries like Bangladesh. However, although high expectations for realizing the benefits of B2B e-Commerce in RMG sectors, its adoption remains poorly understood and are a relatively under-researched area in Bangladesh. This study is an attempt to fill this gap. This study explores the factors that affect B2B e-Commerce adoption in RMG sectors of Bangladesh by using Perceived eReadiness Model (PERM). A questionnaire survey was used to collect data from over 250 RMG firms in Bangladesh. The data was analyzed by using the Partial Least Squares (PLS) method; a statistical analysis technique based on the Structural Equation Model. The study found that awareness, resources, government eReadiness, and market forces eReadiness were significant factors for initial adoption of $B 2 B$ e-Commerce. However, commitment, governance, and supporting industries eReadiness are insignificant for initial adoption of B2B e-Commerce. Again, the relationships between resources, commitment, government eReadiness, market forces eReadiness, supporting industries eReadiness and institutionalization of B2B e-Commerce are significant in $R M G$ sectors of Bangladesh. However, awareness, governance and institutionalization of B2B e-Commerce are insignificant. The output of the study can help RMG firms in Bangladesh to address the factors that influence adoption of B2B e-Commerce. This study can also help the policy maker and government to identify the promising local opportunities for B2B e-Commerce by discovering the distinctive e-Commerce adoption factors.
\end{abstract}

Keywords: E-Commerce, developing countries, B2B, Ready Made Garment Industry

Citation: Hoque, M. R. and Boateng, R. (2017). "Adoption of B2B e-Commerce in Developing Countries: Evidence from Ready Made Garment (RMG) Industry in Bangladesh," Pacific Asia Journal of the Association for Information Systems, 9(1), pp. 55-74. 


\section{Introduction}

B2B e-Commerce has changed the pattern of business transactions conducted between firms domestically as well as globally and has provided extensive benefits to organisations in developing countries (Gao and Duncombe, 2014). Specifically, it improves customer service, reduces marketing and distribution costs, enhances inventory control, and minimizes operational costs of RMG firms in developing countries (Tarofder et al., 2013). Recently investigators have examined that approximately 80 percent of global e Commerce are B2B e-Commerce. According to eMarketer, an e-Commerce research firm, globally Business-toBusiness (B2B) e-Commerce revenue reached \$2.2 trillion in 2013, representing growth of $25.5 \%$ over 2012 (IDC, 2014). Side by side, apparel is the second largest product category in online sales, representing $\$ 50$ billion in projected sales in 2014 (Schonfeld, 2012).

In recent years, $\mathrm{B} 2 \mathrm{~B}$ e-Commerce is increasingly becoming an important area in developing countries for promoting economic growth and welfare (Lin, Huang and Burn, 2013). It provides two-fold opportunities for the developing countries; it enables firms of developing countries to participate in the international market; again, it allows them to buy raw materials from the developed world at least possible time (Lal, 2004). Moreover, e-Commerce can contribute to economic and social development in developing countries (Boateng, Heeks, Molla, and Hinson, 2008).

In the present decade, the Ready-Made Garments (RMG) industry has emerged as a major garment producer in global garment business and successfully transformed Bangladesh into an export-oriented economy (Ahmed et al., 2014). It became a key player in the economy within a short period. It started its journey in the 1970s and has expanded melodramatically over the last three decades. Currently, there are
5700 RMG firms in Bangladesh and 95\% of those firms are owned locally (Rayhan, Saha and Hassan, 2014). The RMG of Bangladesh is one of the major foreign currency earning sectors with highest rates of absorption of industrial employment (Morshed, 2007). About four million people are employed in the RMG sector of Bangladesh and majority (80 percent) of them are women (Islam et al., 2013).

Although Bangladesh has made remarkable progress in ICT, there are still some inadequate building blocks. These building blocks support RMG sectors of Bangladesh to adopt e-Commerce applications. However, a major problem with this kind of application is that some barriers such as electronic fund transfer, infrastructure, legal framework, government support are still prevailing in association with the adoption of Business-to-Business (B2B) e-Commerce in RMG sectors of Bangladesh (Noor and Arif, 2011). In 2013, the country was ranked 119 out of the 148 countries rated in the Networked Readiness Index (NRI), which measures the competitiveness of nations to exploit the opportunities offered by ICTs (WEF, 2013). Similarly, in the 2013 ICT Development Index (IDI), globally agreed set of ICT indicators constructed by the UN's International Telecommunication Union (ITU), Bangladesh ranked 135 out of 157 with a score of 1.73 (ITU, 2013). According to e-Government Development Index (EGDI), one of the most comprehensive indicators evaluating the impact of ICT on the political economy arrangements, Bangladesh ranked 150 out of 179 countries (UN, 2012). In the context of Internet availability and infrastructure, Bangladesh ranked 73 in the world (BilbaoOsorio et al., 2013).

Bangladesh is considered lagging behind in terms of e-Readiness, Networked Readiness and e-government readiness. Moreover, the smallest number of firms involved in B2B e-Commerce has also indicated that Bangladesh has not been an active B2B e-Commerce player (Azam and Quaddus, 2013). This condition is, 
nevertheless, the fact that only few researches have done to analyse the development of e-Commerce in Bangladesh (Hossain, Ali, Kibria and Bhuiyan, 2013). In addition, most of these studies have found low adoption of B2B e-Commerce in RMG sectors. Further research into the adoption of e-Commerce is required to understand the main barriers for adopting B2B eCommerce among RMG firms in Bangladesh.

A recent study has found a low adoption of e-Commerce in Bangladesh (Hoque, Ali and Mahfuz, 2015). However, the adoption of an e-Commerce scenario at firm level was not discussed. Thus, future research is needed to identify the level of e-Commerce adoption at firm level. Hossain et al. (2013) found that the use of Business-to-Consumer (B2C) eCommerce in Bangladesh did not flourish because of low per capita income, a defective infrastructure and legal issues, lack of trust between consumers and business. However, their study describes just B2C e-Commerce, not B2B eCommerce. Azam (2007) examined the effects of buying culture and infrastructural forces in adoption of Business-to-Consumer (B2C) e-Commerce in Bangladesh. The study incorporated a multiple regression analysis that reported that buying culture of the nation's citizen has negative influence on the adoption of B2C e-Commerce in Bangladesh.

Most of the previous studies have focused on B2C commerce and user perspective. Arguably, no study has been conducted on B2B e-Commerce adoption in the RMG sectors of Bangladesh. Theoretically, studies on e-commerce have utilized frameworks such as the Technology Acceptance Model, Theory of Planned Behaviour and the TOE frameworks to understand for e-commerce adoption by firms (Awa, Ojiabo and Emecheta, 2015). This study is an attempt to fill this gap. This study explores the factors that affect B2B eCommerce adoption in RMG sectors of Bangladesh by using the Perceived eReadiness Model (PERM).

\section{B2B e-Commerce Adoption in Developing Countries}

Recently investigators have examined that many developed countries have rapidly adopted e-Commerce during the last two decades due to the potential of B2B eCommerce (Kurnia, Karnali and Rahim, 2015). According to Frost and Sullivan, B2B e-Commerce market will be twice - $\$ 6.7$ trillion vs. $\$ 3.2$ trillion - as large as the $\mathrm{B} 2 \mathrm{C}$ market globally by 2015 . In the U.S., B2B eCommerce is already twice as large as B2C e-Commerce.

More recently, a significant growth of $\mathrm{B} 2 \mathrm{~B}$ eCommerce has been observed in developing countries (Kurnia, Karnali and Rahim, 2015). As a result, developing countries have paid much attention to use B2B e-Commerce in their national trade strategies. B2B e-Commerce sales in the Asian region have increased despite the financial crisis. In China, B2B online sales will reach $\$ 2.1$ trillion, whereas the India will reach $\$ 6$ billion, 70 percent increase over 2014, by 2015. B2B e-Commerce accounted for 91 percent of all e-Commerce in South Korea. In Bangladesh, the size of the $\mathrm{B} 2 \mathrm{~B}$ e-Commerce market has been estimated to be more than Tk. 300 crore by 2015.

The study offers some important insights that the adoption of B2B e-Commerce in developing countries differs significantly from developed countries. They encounter a set of adoption problems that vary considerably from those faced by developed countries. Social, economic, cultural, political, legal and technological conditions in developing countries are greatly different from developed countries, which influence the adoption of B2B e-Commerce (Chaffey, 2011). Furthermore, most of the businesses in developing countries are small which has the lack of adequate resources required to invest in e-Commerce (Goode and Stevens, 2000). Developing countries often lack the necessary physical, legal, and financial infrastructures for the development of e- 
Commerce. It is also found that developing countries have different business philosophies and cultures (Gibbs, Kraemer and Dedrick, 2003; Hemple and Kwong, 2001). Tan, Tyler and Manica (2007) found that intolerance towards failure, lack of enterprise-wide information sharing, lack of internal trust and inability of dealing with rapid change are the most important problems of $\mathrm{B} 2 \mathrm{~B}$ e-Commerce adoption in China.

The factors affecting B2B e-Commerce adoption in developing countries are listed in Table 1.

Table 1 - B2B e-Commerce Adoption in Developing Countries

\begin{tabular}{|c|c|c|}
\hline Country & Source & $\begin{array}{c}\text { Factors } \\
\end{array}$ \\
\hline Nigeria & Olatokun and Bankole (2011) & $\begin{array}{l}\text { Size of business, awareness, perceived } \\
\text { benefits. }\end{array}$ \\
\hline Oman & $\begin{array}{l}\begin{array}{l}\text { Al-Balushi, } \\
\text { (2011) }\end{array} \\
\text { Al Badi and Ali }\end{array}$ & $\begin{array}{l}\text { Culture, government support, industry } \\
\text { characteristics, Management support }\end{array}$ \\
\hline Pakistan & Seyal et al. (2004) & $\begin{array}{l}\text { Perceived benefits, government support, } \\
\text { organizational culture }\end{array}$ \\
\hline Saudi Arabia & $\begin{array}{l}\text { Al-Somali, Gholami and Clegg } \\
\text { (2011) }\end{array}$ & $\begin{array}{l}\text { Customer pressure, Organisational IT } \\
\text { readiness, management support }\end{array}$ \\
\hline China & Tan, Tyler and Manica (2007) & $\begin{array}{l}\text { Intolerance towards failure, lack of } \\
\text { enterprise-wide information sharing, lack of } \\
\text { internal trust and incapability of dealing with } \\
\text { rapid change }\end{array}$ \\
\hline Vietnam & Pham et al. (2011) & $\begin{array}{l}\text { Organisation size, management support, } \\
\text { perceived benefits, compatibility, } \\
\text { competitiveness }\end{array}$ \\
\hline India & Tarafdar and Vaidya (2006) & $\begin{array}{l}\text { Organisation structure, } \\
\text { support, organizational culture }\end{array}$ \\
\hline Kenya & $\begin{array}{l}\text { Kenneth, Rebecca and Eunice } \\
\text { (2012) }\end{array}$ & $\begin{array}{l}\text { Management support, leadership, national } \\
\text { infrastructure }\end{array}$ \\
\hline Vietnam & Tran et al. (2014) & $\begin{array}{l}\text { Government, IT infrastructure, Legal and } \\
\text { regulatory infrastructure, Top managers' IT } \\
\text { ability and perception, Socio-economic and } \\
\text { knowledge infrastructure }\end{array}$ \\
\hline Ghana & $\begin{array}{l}\text { Asare, } \quad \text { Gopolang } \\
\text { Mogotlhwane (2012) }\end{array}$ & $\begin{array}{l}\text { ICT Infrastructure, Technical know-how, } \\
\text { Power disruption }\end{array}$ \\
\hline Malaysia & Chong et al. (2011) & $\begin{array}{l}\text { Lack confidence, available technology, lack } \\
\text { of technical and knowledge resources }\end{array}$ \\
\hline Bangladesh & Noor and Arif (2011) & $\begin{array}{l}\text { Internal organisational capability, IT } \\
\text { infrastructure, skilled human resources, } \\
\text { proper business strategy and lack of fund. }\end{array}$ \\
\hline
\end{tabular}

Although Bangladesh has planned to improve the utilization of ICT and the number of Internet users has reached 47 million at the end of June 2015, Bangladesh government has not yet succeeded in implementing of e-Commerce applications (BTRC, 2015). In addition, weak telecommunication and e-Banking infrastructure also obstructs development of
e-Commerce in Bangladesh (Hossain, 2000). Ali (2010) argued that information regarding Internet banking services and its benefits is a critical factor influencing the adoption of e-Commerce in Bangladesh. Recently Hoque, Ali and Mahfuz (2015) have shown an increased interest in the adoption of e-Commerce in Bangladesh and found that organisational culture, resistance 
to change; proper strategy and lack of technical and human resources have significantly influence on the adoption of eCommerce.

\section{Theoretical Framework}

Most of the previous studies based on technology adoption theories emphasize on the adoption of IT and e-Commerce at individual level (Lu et al., 2005; Venkatesh, 2006). Until recently, a few studies have tried to investigate the adoption of eCommerce at organisational level by addressing a wide variety of perspectives such as organisational change (Moreton, 1995), managerial action (Daniel, Wilson and Myers, 2002), the institutional context (Sahay and Robey, 1996); and the political and social context (Cousins and Robey, 2005). Although, some researchers have tried to mix the organisational, innovation, and environmental imperatives in their study (Vaithianathan, 2010; Seyal et al., 2004), quite a few attempts have been taken to balance the organisational, innovation, and environmental perspectives on adoption of
e-Commerce in developing countries such as Bangladesh (Molla and Licker, 2005).

Literature on e-Commerce showed the clear lack of appropriate theoretical and conceptual model to examine e-Commerce adoption in developing countries. Moreover, most of the theories and models were designed and applied for developed countries. However, a new stream of literature called "eReadiness" has also emerged in relation to e-Commerce adoption and many nations have already been assessed for their eReadiness (Tan, Tyler and Manica, 2007), almost all of the eReadiness assessment models are also based on developed countries. Moreover, the findings of such studies, tend to examine businesses in the developed countries, are hardly generalizable because of the apparent differences in the social, business, economic, and technological contexts of developed and developing countries. Thus, the Perceived eReadiness Model (PERM) developed by Molla and Licker (2005) is only one comprehensive model in the context of developing countries, which identifies environmental and organisational factors that affect eCommerce adoption (Figure1).

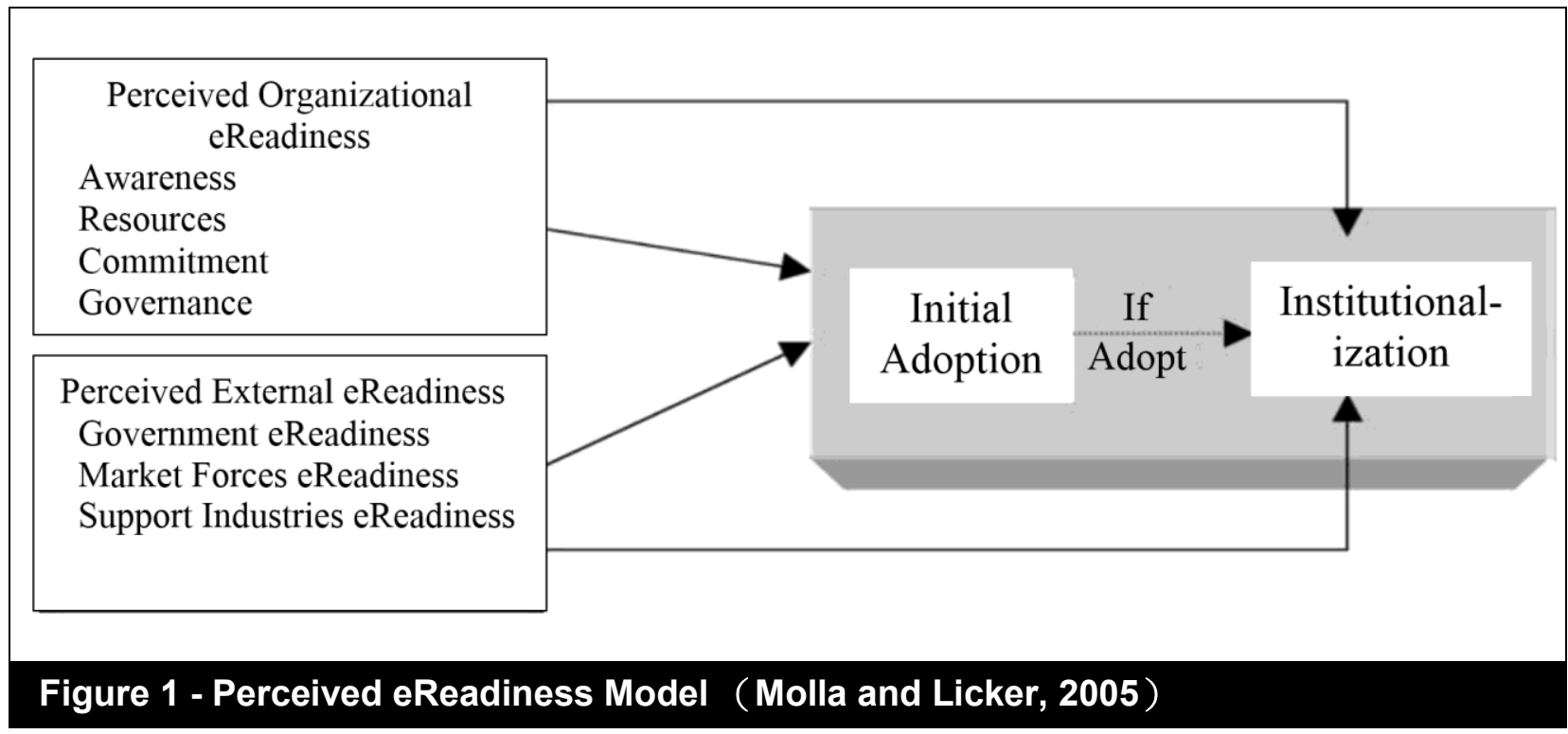


The PERM Model is more comprehensive than any other earlier models, because it includes both internal organisational and external environmental issues (Al-Hudhaif and Alkubeyyer, 2011). It is also more relevant, because it is particularly designed for developing countries. In addition, this model examines its institutionalization, beyond the initial adoption of e-Commerce, which few models to date have covered (Molla and Licker, 2005). In the PERM model, perceived eReadiness is defined "as an organisation's assessment of the eCommerce, managerial, organisational and external situations in making decision about adopting e-Commerce" (Molla and Licker, 2005:879). The PERM model postulates that an organisation's perception of its internal and external eReadiness influences both the initial adoption of e-Commerce and the subsequent institutionalization of $\mathrm{e}$ Commerce. It includes two major constructs- Perceived Organisational eReadiness (POER) and Perceived External eReadiness (PEER) which measure initial adoption of e-Commerce and the subsequent institutionalization of eCommerce (Molla and Licker, 2005).

\section{Perceived Organisational eReadiness (POER)}

The Perceived Organisational eReadiness (POER) is defined as "managers' perception and evaluation of the degree to which they believe that their organisation has the awareness, resources, commitment, and governance to adopt e-Commerce" (Molla and Licker, 2005:879). Therefore, the POER has four components such as awareness (innovation context), resources, commitment (managerial context), and governance (organisational context). The hypotheses generated from the POER constructs therefore include:

\section{Awareness \\ Hypothesis 1a: Awareness is positively related to initial adoption of $B 2 B$ e- Commerce in Bangladesh.}

Hypothesis 1b: Awareness is positively related to the institutionalization of $B 2 B$ eCommerce in Bangladesh.

\section{Resources}

Hypothesis 2a: Resources are positively related to the initial adoption of $B 2 B$ eCommerce in Bangladesh.

Hypothesis 2b: Resources are positively related to the institutionalization of $B 2 B$ eCommerce in Bangladesh.

\section{Commitment}

Hypothesis 3a: Commitment is positively related to the initial adoption of $B 2 B$ eCommerce in Bangladesh.

Hypothesis 3b: Commitment is positively related to the institutionalization of $B 2 B$ eCommerce in Bangladesh.

\section{Governance}

Hypothesis 4a: Governance is positively related to the initial adoption of $B 2 B$ eCommerce in Bangladesh.

Hypothesis 4b: Governance is positively related to the institutionalization of $B 2 B$ eCommerce in Bangladesh.

\section{Perceived External eReadiness (PEER)}

The Perceived External eReadiness (PEER) is defined "as the degree to which managers believe that market forces, government, and other supporting industries are ready to aid in their organisations' $e$ Commerce implementation" (Molla and Licker, 2005:879). It includes government eReadiness, market forces eReadiness and supporting industries eReadiness. Therefore, these factors are used to construct the hypotheses as follows.

\section{Government eReadiness}

Hypothesis 5a: Government e-readiness is positively related to the initial adoption of B2B e-Commerce in Bangladesh.

Hypothesis 5b: Government e-readiness is positively related to the institutionalization of B2B e-Commerce in Bangladesh. 


\section{Market Forces eReadiness}

Hypothesis 6a: Market forces e-readiness is positively related to initial adoption of $B 2 B$ e-Commerce in Bangladesh.

Hypothesis 6b: Market forces e-readiness is positively related to the institutionalization of $B 2 B$ e-Commerce in Bangladesh.

\section{Supporting Industries eReadiness}

Hypothesis 7a: Support industries ereadiness is positively related to initial adoption of B2B e-Commerce in Bangladesh.

Hypothesis 7b: Support industries ereadiness is positively related to the institutionalization of $\mathrm{B} 2 \mathrm{~B}$ e-Commerce in Bangladesh.

Finally, the initial adoption means, "a business is considered to have adopted eCommerce if it has achieved an interactive e-Commerce status", while institutionalization of e-Commerce indicates, "whether or not an organisation has attained an interactive, or transactive or integrated eCommerce status" (Molla and Licker, 2005:882). Al-Hudhaif and Alkubeyyer (2011) found that initial adoption of eCommerce contributes positively to the institutionalization of e-Commerce. Molla and Licker (2005) revealed that initial adoption is likely to have a significant impact on the institutionalization of eCommerce. Institutionalization in this context refers to the usage of e-Commerce across the organization which is corroborated by Nielsen, Mathiassen and Newell (2014). Therefore, this study proposed the following hypothesis:

Hypothesis 8: Initial adoption of $B 2 B$ eCommerce is positively related to the institutionalization of B2B e-Commerce in Bangladesh.

\section{Research Methodology}

\section{Research Setting}

In view of limited previous research on the adoption of e-Commerce, especially in the context of Bangladesh, an exploratory research is most justifiable (Zikmund et al., 2010). A positivism approach is deemed appropriate for this research to investigate the intention and acceptance of B2B eCommerce (Lee, 1991). A quantitative, cross-sectional survey was used in this research. The survey research strategy is a well-understood data collection tool used by scholars to gather information from study participants. It has been successfully applied for many years and has precise procedures, produce valid and easily interpretable data (Pinsonneault and Kraemer, 1993). Moreover, this strategy is a feasible means to develop measurement scales, test hypotheses, build theoretical models and describe populations in research across a wide range of fields (Lee and Shim, 2007). In survey, information from a sample of people can make some conclusion about the wider population. The survey questionnaire method was selected in this study for its utility in collecting primary data (Lewis, Thornhill and Saunders, 2007).

\section{Measurements}

All measures for latent constructs within the proposed model was developed from prior studies and modified in the context of B2B e-Commerce in Bangladesh. Most of the variables was scored on a 5-point Likert response scale (from " 1 " = strongly disagree" to " 5 " = strongly agree") with high scores representing greater standing on the variables of interest. Age was measured in years. Gender was measured as a dichotomous variable (i.e., $1=$ male, $0=$ female). 


\section{Questionnaire Design and Data Collection}

The research questionnaire had three parts. Part $A$ includes the relevant information regarding the organisation, while Part $B$ covers the demographic questions of the respondents. Part C contains questionnaires for the different constructs in research model. A pilot study of twenty samples was conducted in a pretest.

The unit of analysis for this study is the organisation because the research objective is to examine the determinants of $\mathrm{B} 2 \mathrm{~B}$ eCommerce adoption amongst RMG firms. The research population was RMG firms within Dhaka city. Among the firms located, only Dhaka was selected for investigation since considering its high internet penetration and most of the organisations have the coordinating unit at Dhaka. In order to obtain some measure of generalizability, a random sampling of businesses listed in BGMEA (Bangladesh Garment Manufacturers and Exporters Association) members' directory was used (Saunders, Lewis and Thornhill, 2011).

\section{Data Analysis}

Data for this study was analysed using the Partial Least Squares (PLS) method, a statistical analysis technique based on the Structural Equation Model (SEM). One of the notable applications of SEM is that it can be applied to explore out the relationships among latent constructs and which are indicated by multiple measures. The unobservable and hard-to-measure latent variables can be used in SEM makes it ideal for tackling research problems (Wong, 2013).

\section{Findings}

\section{Sample Demographics}

This section presents the sample demographics. Firstly, the sample firms are profiled by the variables of year in business, number of employees, organisation's ICT usages experience. Secondly, the respondents from selected firms are profiled by the variables of age, gender, position, IT usage experience (Table 2). The majority of the firms sampled (79 percent) had established ranged from 3 to 11 years, while only one percent had been established for more than 27 years. It is also noted that only two percent had been established for less than 3 years. Almost 50 percent of sampled firms had 3-5 years ICT usage experience. The majority of the firms (78 percent) had more than 100 employees.

\section{Measurement Model (Validity and Reliability)}

We assessed the measurement model by examining the internal reliability, convergent and discriminant validity. The internal reliability was evaluated considering Cronbach's alpha and composite reliability. For acceptable internal consistency, the value of Cronbach's alpha and composite reliability should be more than 0.70 (Hair et al., 2013a). These are detailed in Table 3 below.

The discriminant validity was assessed by the square root of the Average Variance Extracted (AVE) and cross loading matrix. For acceptable discriminant validity, diagonal elements should be larger than the entries in corresponding rows and columns (Hair et al., 2013b). It was revealed that the square roots of the AVE for each construct were significantly higher than the corresponding correlations among the latent constructs. So, the study fulfils discriminant validity as shown in Table 4 below. 


\begin{tabular}{|c|c|c|}
\hline Description & Frequency & Percentage \\
\hline \multicolumn{3}{|l|}{ Year in Business } \\
\hline Less than 3 years & 3 & $2 \%$ \\
\hline 3 to 7 years & 62 & $34 \%$ \\
\hline 7 to 11 years & 82 & $45 \%$ \\
\hline 11 to 15 years & 15 & $9 \%$ \\
\hline 15 to 19 years & 6 & $3 \%$ \\
\hline 19 to 23 years & 4 & $2 \%$ \\
\hline 23 to 27 years & 7 & $4 \%$ \\
\hline More than 27 years & 2 & $1 \%$ \\
\hline Total & 181 & $100 \%$ \\
\hline \multicolumn{3}{|l|}{ No of Employees } \\
\hline Less than 25 & 7 & $4 \%$ \\
\hline 25- 50 employees & 12 & $7 \%$ \\
\hline $51-100$ employees & 19 & $11 \%$ \\
\hline 101 - 150 employees & 75 & $41 \%$ \\
\hline $151-200$ employees & 17 & $9 \%$ \\
\hline 201- 250 employees & 23 & $13 \%$ \\
\hline More than 250 employees & 28 & $15 \%$ \\
\hline Total & 181 & $100 \%$ \\
\hline \multicolumn{3}{|l|}{$\begin{array}{l}\text { Organisation's ICT using } \\
\text { Experience }\end{array}$} \\
\hline Less than 2 years & 34 & $19 \%$ \\
\hline $3-5$ years & 88 & $49 \%$ \\
\hline 6-8 Years & 42 & $23 \%$ \\
\hline $9-12$ years & 13 & $7 \%$ \\
\hline $13-16$ years & 4 & $2 \%$ \\
\hline Total & 181 & $100 \%$ \\
\hline \multicolumn{3}{|c|}{ Your Position in organisation } \\
\hline Owner & 10 & $6 \%$ \\
\hline CEO & 51 & $28 \%$ \\
\hline IS Manager & 120 & $66 \%$ \\
\hline Total & 181 & $100 \%$ \\
\hline \multicolumn{3}{|l|}{ Gender } \\
\hline Male & 147 & $81 \%$ \\
\hline Female & 34 & $19 \%$ \\
\hline Total & 181 & $100 \%$ \\
\hline \multicolumn{3}{|l|}{ Age } \\
\hline Less than 20 years & 2 & $1 \%$ \\
\hline $21-30$ years & 61 & $33 \%$ \\
\hline $31-40$ years & 94 & $52 \%$ \\
\hline $41-50$ years & 21 & $12 \%$ \\
\hline More than 50 years & 3 & $2 \%$ \\
\hline Total & 181 & $100 \%$ \\
\hline \multicolumn{3}{|l|}{ IT usage experience } \\
\hline Less than 1 years & 4 & $2 \%$ \\
\hline $1-3$ years & 45 & $25 \%$ \\
\hline 4-6 years & 82 & $45 \%$ \\
\hline $7-9$ years & 43 & $24 \%$ \\
\hline More than 10 years & 7 & $4 \%$ \\
\hline Total & 181 & $100 \%$ \\
\hline
\end{tabular}




\begin{tabular}{|c|c|c|c|}
\hline & AVE & Composite Reliability & Cronbachs Alpha \\
\hline AWA & 0.8582 & 0.9769 & 0.9725 \\
\hline COM & 0.7149 & 0.9260 & 0.9008 \\
\hline GOR & 0.8787 & 0.9560 & 0.9311 \\
\hline GOV & 0.7498 & 0.9374 & 0.9173 \\
\hline INA & 0.7175 & 0.8839 & 0.8030 \\
\hline INS & 0.6494 & 0.8465 & 0.7285 \\
\hline MFR & 0.8073 & 0.9437 & 0.9205 \\
\hline RES & 0.7389 & 0.9714 & 0.9678 \\
\hline SIR & 0.7593 & 0.9042 & 0.8544 \\
\hline
\end{tabular}

\section{Table 4 - Correlation matrix and square root of the AVE}

\begin{tabular}{|l|r|r|r|r|r|r|r|r|l|}
\hline & \multicolumn{1}{|c|}{ AWA } & COM & GOR & GOV & INA & INS & MFR & RES & SIR \\
\hline AWA & $\mathbf{0 . 9 2 6 4}$ & & & & & & & & \\
\hline COM & 0.0879 & $\mathbf{0 . 8 4 5 5}$ & & & & & & & \\
\hline GOR & 0.2205 & 0.1357 & $\mathbf{0 . 9 3 7 4}$ & & & & & & \\
\hline GOV & 0.1114 & 0.1959 & 0.1821 & $\mathbf{0 . 8 6 5 9}$ & & & & & \\
\hline INA & 0.3733 & 0.2116 & 0.4721 & 0.2124 & $\mathbf{0 . 8 4 7 1}$ & & & & \\
\hline INS & 0.1648 & 0.2139 & 0.3472 & 0.1857 & 0.4703 & $\mathbf{0 . 8 0 5 9}$ & & & \\
\hline MFR & 0.2689 & 0.1981 & 0.2249 & 0.1325 & 0.4388 & 0.3887 & $\mathbf{0 . 8 9 8 5}$ & & \\
\hline RES & 0.2902 & 0.1640 & 0.3032 & 0.2610 & 0.5122 & 0.4015 & 0.4647 & $\mathbf{0 . 8 5 9 6}$ & \\
\hline SIR & 0.0355 & 0.0585 & -0.0328 & -0.0312 & 0.1015 & 0.0910 & 0.0956 & 0.0006 & $\mathbf{0 . 8 7 1 4}$ \\
\hline
\end{tabular}

AWA: Awareness, COM: Commitment, GOR: Government eReadiness, GOV: Governance, INA: Adoption, INS: Institutionalization, MFR: Market Forces eReadiness, RES: Resources, SIR: Supp Industries eReadiness.

All of the measures in the research model were shown to be internally consistent and to demonstrate sufficient levels of validity. Therefore, the collected data and findings that were obtained from this instrument are reliable.

\section{Structural Model (Hypothesis Testing)}

The PLS results for the structural model are shown in Table 5 . The results show that the relationships between awareness and initial adoption of B2B e-Commerce $(t=2.2106, \beta$ $=0.1594, p=0.043)$, resources and initial adoption of B2B e-Commerce $(t=3.5189, \beta$ $=0.2607, p=0.000)$, government
eReadiness and initial adoption of B2B eCommerce $(t=3.5485, \beta=0.3010, p=$ $0.000)$ and market forces eReadiness and initial adoption of B2B e-Commerce $(t=$ 2.7063, $\beta=0.1656, p=0.006$ ) are significant. However, commitment and initial adoption of B2B e-Commerce $(t=0.9157, \beta$ $=0.0639, p=0.361)$, governance and initial adoption of B2B e-Commerce $(t=0.4621, \beta$ $=0.0430, p=0.681)$ and supporting industries eReadiness and initial adoption of B2B e-Commerce $(t=1.1301, \beta=0.0737, p$ $=0.243)$ are insignificant. Thus, $\mathrm{H} 1 \mathrm{a}, \mathrm{H} 2 \mathrm{a}$, $\mathrm{H} 5 \mathrm{a}$ and $\mathrm{H} 6 \mathrm{a}$ are supported, while $\mathrm{H} 3 \mathrm{a}$, $\mathrm{H} 4 \mathrm{a}$ and $\mathrm{H} 7 \mathrm{a}$ are not. 


\begin{tabular}{|l|c|c|c|}
\hline \multicolumn{1}{|l|}{ Table 5 - Structural Model } \\
\hline & $B$ & $t$-Statistics & $P$-Value \\
\hline AWA -> INA & 0.1594 & 2.2106 & 0.043 \\
\hline AWA -> INS & 0.0744 & 1.9296 & 0.444 \\
\hline COM -> INA & 0.0639 & 0.9157 & 0.361 \\
\hline COM -> INS & 0.1308 & 1.9642 & 0.045 \\
\hline GOR -> INA & 0.3010 & 3.5485 & 0.000 \\
\hline GOR -> INS & 0.1394 & 2.7905 & 0.039 \\
\hline GOV -> INA & 0.0430 & 0.4621 & 0.681 \\
\hline GOV -> INS & 0.0191 & 0.4653 & 0.550 \\
\hline INA -> INS & 0.4666 & 4.0334 & 0.016 \\
\hline MFR -> INA & 0.1656 & 2.7063 & 0.006 \\
\hline MFR -> INS & 0.0797 & 2.0773 & 0.035 \\
\hline RES -> INA & 0.2607 & 3.5189 & 0.000 \\
\hline RES -> INS & 0.1253 & 2.3631 & 0.037 \\
\hline SIR -> INA & 0.0737 & 1.1301 & 0.243 \\
\hline SIR -> INS & 0.1365 & 1.9784 & 0.044 \\
\hline Critical t-value: $1.96, p<0.05$ & & \\
\hline
\end{tabular}

The results also show that the relationships between resources and institutionalization of B2B e-Commerce $(t=2.3631, \beta=0.1253$, $p=0.037$ ), commitment and institutionalization of B2B e-Commerce $(t=$ 1.9642, $\beta=0.1308, p=0.045)$, government eReadiness and institutionalization of $\mathrm{B} 2 \mathrm{~B}$ e-Commerce $(t=2.7905, \beta=0.1394, p=$ 0.039), market forces eReadiness and institutionalization of B2B e-Commerce $(t=$ 2.0773, $\beta=0.0797, p=0.035$ ) and supporting industries eReadiness and institutionalization of B2B e-Commerce $(t=$ 1.9784, $\beta=0.1365, \quad p=0.044$ ) are significant. However, awareness and institutionalization of B2B e-Commerce $(t=$ 1.9296, $\beta=0.0744, p=0.444)$, governance and institutionalization of B2B e-Commerce $(t=0.4653, \beta=0.0191, p=0.550)$ are insignificant. Thus, $\mathrm{H} 2 \mathrm{~b}, \mathrm{H} 3 \mathrm{~b}, \mathrm{H} 5 \mathrm{~b}, \mathrm{H} 6 \mathrm{~b}$ and $\mathrm{H} 7 \mathrm{~b}$ are supported, while $\mathrm{H} 1 \mathrm{~b}$ and $\mathrm{H} 4 \mathrm{~b}$ are not.

Finally, this study found that initial adoption of B2B e-Commerce $(t=4.0334, \beta=0.4666$, $p=0.016)$ significantly influence institutionalization of B2B e-Commerce. So, $\mathrm{H} 8$ are supported. The result also indicated that our research model can explain $48.9 \%$ of the variance in initial adoption of B2B eCommerce $\left(R^{2}=0.489\right)$ and $31.3 \%$ of the variance in institutionalization of $\mathrm{B} 2 \mathrm{~B}$ eCommerce $\left(R^{2}=0.313\right)$. The summary of result is shown in Table 6 . 


\begin{tabular}{|c|c|c|}
\hline & Hypothesis & Remarks \\
\hline $\mathrm{H} 1 \mathrm{a}$ & $\begin{array}{l}\text { Awareness is positively related to initial adoption of B2B e- } \\
\text { Commerce in Bangladesh. }\end{array}$ & Supported \\
\hline $\mathrm{H} 1 \mathrm{~b}$ & $\begin{array}{l}\text { Awareness is positively related to the institutionalization of B2B e- } \\
\text { Commerce in Bangladesh. }\end{array}$ & Not Supported \\
\hline $\mathrm{H} 2 \mathrm{a}$ & $\begin{array}{l}\text { Resources are positively related to initial adoption of B2B e- } \\
\text { Commerce in Bangladesh. }\end{array}$ & Supported \\
\hline $\mathrm{H} 2 \mathrm{~b}$ & $\begin{array}{l}\text { Resources are positively related to the institutionalization of B2B } \\
\text { e-Commerce in Bangladesh. }\end{array}$ & Supported \\
\hline $\mathrm{H} 3 \mathrm{a}$ & $\begin{array}{l}\text { Commitment is positively related to initial adoption of B2B e- } \\
\text { Commerce in Bangladesh. }\end{array}$ & Not Supported \\
\hline $\mathrm{H} 3 \mathrm{~b}$ & $\begin{array}{l}\text { Commitment is positively related to the institutionalization of B2B } \\
\text { e-Commerce in Bangladesh. }\end{array}$ & Supported \\
\hline $\mathrm{H} 4 \mathrm{a}$ & $\begin{array}{l}\text { Governance is positively related to initial adoption of B2B e- } \\
\text { Commerce in Bangladesh. }\end{array}$ & Not Supported \\
\hline $\mathrm{H} 4 \mathrm{~b}$ & $\begin{array}{l}\text { Governance is positively related to the institutionalization of B2B } \\
\text { e-Commerce in Bangladesh }\end{array}$ & Not Supported \\
\hline $\mathrm{H} 5 \mathrm{a}$ & $\begin{array}{l}\text { Government e-readiness is positively related to initial adoption of } \\
\text { B2B e-Commerce in Bangladesh. }\end{array}$ & Supported \\
\hline $\mathrm{H} 5 \mathrm{~b}$ & $\begin{array}{l}\text { Government e-readiness is positively related to the } \\
\text { institutionalization of B2B e-Commerce in Bangladesh. }\end{array}$ & Supported \\
\hline $\mathrm{H} 6 \mathrm{a}$ & $\begin{array}{l}\text { Market forces e-readiness is positively related to initial adoption of } \\
\text { B2B e-Commerce in Bangladesh. }\end{array}$ & Supported \\
\hline $\mathrm{H} 6 \mathrm{~b}$ & $\begin{array}{l}\text { Market forces e-readiness is positively related to the } \\
\text { institutionalization of B2B e-Commerce in Bangladesh. }\end{array}$ & Supported \\
\hline $\mathrm{H} 7 \mathrm{a}$ & $\begin{array}{l}\text { Support industries e-readiness is positively related to initial } \\
\text { adoption of B2B e-Commerce in Bangladesh. }\end{array}$ & Not Supported \\
\hline $\mathrm{H} 7 \mathrm{~b}$ & $\begin{array}{l}\text { Support industries e-readiness is positively related to the } \\
\text { institutionalization of B2B e-Commerce in Bangladesh. }\end{array}$ & Supported \\
\hline $\mathrm{H} 8$ & $\begin{array}{l}\text { Initial adoption of B2B e-Commerce is positively related to the } \\
\text { institutionalization of B2B e-Commerce in Bangladesh. }\end{array}$ & Supported \\
\hline
\end{tabular}

\section{Discussion}

In previous section, this study has examined and analysed different factors that influence B2B e-Commerce adoption in RMG sectors of Bangladesh by Molla and Licker (2005) Perceived eReadiness Model (PERM). The findings of the study are discussed in this section.

\section{Initial Adoption}

This study found that awareness, resources, government e-readiness, and market forces e-readiness are the significant factors, which influence the initial adoption of B2B eCommerce in the RMG sectors of
Bangladesh, while commitment, governance and support industries e-readiness had no significant impact on the initial adoption of B2B e-Commerce in the RMG sectors of Bangladesh.

This study infers that awareness is an important factor that influences initial adoption of B2B e-Commerce in the RMG sectors of Bangladesh. The literature on technology adoption agrees that awareness about e-Commerce and its benefits affect the decision to adopt or reject new technology such as B2B e-Commerce (Licker, 1997). Apparently, B2B eCommerce awareness has to be an important consideration in the investigation 
of B2B e-Commerce adoption in the RMG sectors of Bangladesh.

The study found that resources such as human and technology have a major impact on initial B2B e-Commerce adoption in RMG sectors of Bangladesh. This finding is consistent with the findings of e-Commerce adoption in developing countries (Kuan and Chau, 2001). The RMG firms in Bangladesh, which have historically accumulated these resources moved to develop them appear to have adopted B2B e-Commerce. Government e-readiness is another major factor influencing initial adoption of B2B eCommerce in RMG sectors of Bangladesh. Most of the previous research in the areas of technology adoption has found that the role of governments in developing countries play important role in promoting eCommerce (Kapurubandara and Lawson, 2006). The policies, protections, regulations, and frameworks put in place affect B2B eCommerce adoption.

Market forces e-readiness was found to have much effect on initial B2B eCommerce adoption in RMG sectors of Bangladesh. From the finding, it can be assumed that the firms that perceive that their partners and customers are ready to conduct business electronically are more likely to adopt e-Commerce than when there is no such perception.

Commitment, governance and support industries e-readiness do not appear to have any significant effect on the initial adoption of B2B e-Commerce adoption among RMG sectors in Bangladesh. Previous research indicated that some organisations move into e-Commerce without a conscious decision by management (Oxley and Yeung, 2001).

Supporting industries (telecommunication, finance and transportation) had no significant effect on B2B e-Commerce adoption in RMG firms of Bangladesh. The result is consistent with the findings of Molla and Licker (2005) which found that supporting industries e-readiness does not have affect initial adoption of e-Commerce in developing countries.

\section{Institutionalization of e-Commerce}

For institutionalization of B2B e-Commerce among RMG sectors in Bangladesh, the main factors and determinants are Perceived External eReadiness (PEER). All Perceived External eReadiness (PEER) factors such as government e-readiness, market forces e-readiness and support industries e-readiness had significant effect on the institutionalization of B2B eCommerce among the RMG sectors in Bangladesh. On the other hand, the study found mixed result in Perceived Organisational eReadiness (POER) factors. Perceived Organisational eReadiness (POER) factors such as resources and commitment are the significant factors which influence the institutionalization of B2B e-Commerce in RMG sectors of Bangladesh, while awareness and governance had no significant impact on institutionalization of $\mathrm{B} 2 \mathrm{~B}$ e-Commerce in RMG sectors of Bangladesh.

Government e-readiness emerged as the most significant factor affecting the level of institutionalization of B2B e-Commerce adoption in Bangladesh. A possible explanation is that this government $e-$ readiness factor is necessary after the adoption stage and the overwhelming significance effect on institutionalization of B2B e-Commerce among RMG sectors in Bangladesh. It is also in sync with the literature on e-Commerce in developing countries, which emphasizes the role of government in facilitating information technology and e-Commerce adoption (Molla and Licker, 2005).

Market forces e-readiness and supporting industries e-readiness are the other significant factors affecting the level of institutionalization of B2B e-Commerce adoption in Bangladesh. This result is consistent with the work of Montealegre (1999) who proposed that, "in less developed countries, institutional 
intervention is essential in the adoption of IT innovations that cut across firm boundaries" (p. 210).

Resources and commitment are the significant factors, which influence the institutionalization of B2B e-Commerce in RMG sectors of Bangladesh. These findings empirically support the argument that the factors that affect initial B2B e-Commerce adoption are different from those that of institutionalization. This is consistent with suggestions of Molla and Licker (2005) that the factors facilitating innovation in its early stage could be the opposite of those facilitating the later stage. In developing countries like Bangladesh, resources are one of the difficult blocks that managers have to face while attempting to institutionalize the B2B e-Commerce (Montealegre, 1996).

However, this study did not find any significant relationship between awareness and institutionalization of B2B e-Commerce in RMG sectors of Bangladesh. This finding is apparently surprising given that many studies using Molla and Licker (2005) PERM model confirm the relationship between awareness and B2B e-Commerce adoption. For example, Al-Hudhaif and Alkubeyyer (2011) found a strong relationship between awareness and institutionalization of B2B e-Commerce adoption. It could be reflective on the fact that most of the sample RMG firms and their partners (customers and supplier) are already aware about benefits and threats, future trend, and requirement of B2B eCommerce.

\section{Implications}

\section{Theoretical Contribution}

This study has several theoretical implications. This study applied Molla and Licker (2005) PERM model to determine the factors that influence the adoption of B2B eCommerce in RMG sectors of Bangladesh. The paper has confirmed the usability of model for identifying different factors toward the adoption of B2B e-Commerce in the context of RMG in Bangladesh. According to our analysis using Molla and Licker's (2005) PERM model, the study found that adoption of B2B e-Commerce are heavily dependent on the external factor, mainly the factors related to government eReadiness, market forces eReadiness and supporting industries eReadiness. This study provides empirical evidence to show that the factors of initial adoption are different from that of institutionalization of $\mathrm{B} 2 \mathrm{~B}$ e-Commerce in RMG sectors of Bangladesh.

\section{Practical Contribution}

This study has implications for policymakers, government and businesspersons. An important lesson from this study is that RMG industry need to view the eCommerce initiative as a critical business area rather than just a technical issue. They need to give more attention to their internal IT staff, management support, existing business relationship and technological resources, which may allow them for initial adoption and institutionalization of eCommerce. Policies and strategies need to be developed with focus on the internal eCommerce adoption factors of the firms. The RMG firms should concentrate on providing the technical resources, training, commitment, and governance of firms and analysing the market forces of the industry.

\section{Study Limitations and Future Research Directions}

The survey questionnaire method was used in this study for data collection. The main problem of survey strategy is biasness. Although random sampling is generally used to select respondents in survey, participants' rates can bias the results of survey (Groves et al., 2013). Unwillingness and inability of respondents are also considered as major disadvantages of survey research strategy (Blair, Czaja and Blair, 2013). It is also argued that the answer choices provided on a survey questionnaire may not be an accurate 
reflection of the participant truly feelings (Fowler, 1995). The firms located only Dhaka was selected for investigation and data were collected from the top-level executives and Information Systems manager. Therefore, it is very difficult to generalize the findings. The study adopted cross-sectional design. The cross-sectional study represents a slice of time and does not show change over time.

Addressing the above identified limitation, potential future study could expand the scope to a larger sample size including the organisation outside of Dhaka. Another future extension of this study could be to integrate other moderators such as socioeconomic status, culture, etc. and a qualitative research for a deeper understanding of users' needs and thoughts. Furthermore, the model proposed in this study can be applied to other sectors in Bangladesh or others developing countries with the same or different contexts.

\section{Concluding Remarks}

The rapid adoption of e-Commerce, especially B2B e-Commerce among RMG firms is a key opportunity for local and international trade development of least developed countries (LDCs) like Bangladesh. However, B2B e-Commerce is not growing at a rapid pace in Bangladesh. This study was an attempt to explore the factors that affect B2B e-Commerce adoption in RMG sectors of Bangladesh. The output of the study can help RMG firms in Bangladesh to address the factors that influence the adoption of B2B e-Commerce. This study can also help the policy maker and government to identify the promising local opportunities for B2B e-Commerce by discovering the distinctive e-Commerce adoption factors. However, unless RMG firms in Bangladesh incorporate eCommerce into their operations, the potential benefit of e-Commerce remains potential and not reality.

\section{References}

Ahmed, F. Z., Greenleaf, A., and Sacks, A. (2014). The Paradox of Export Growth in Areas of Weak Governance: The Case of the Ready Made Garment Sector In Bangladesh. World Development, 56, pp.258-271.

Al-Balushi, T., Al-Badi, A. H., \& Ali, S. (2011). Prevalence of disability in Oman: statistics and challenges. Canadian Journal of Applied Sciences, 1(3), pp. 81-96.

Al-Hudhaif, S. A., and Alkubeyyer, A. (2011). E-commerce adoption factors in Saudi Arabia. International Journal of Business and Management, 6(9), pp.122.

Ali, M. M. (2010). E-Commerce and on line banking in Bangladesh: an Analysis. AIUB Business and Economics Working Paper Series.

Al-Somali, S. A., Gholami, R., and Clegg, B. (2011). Determinants of B2B ecommerce adoption in Saudi Arabian firms. International Journal of Digital Society (IJDS), 2(2), pp.406-415.

Asare, S. D., Gopolang, B., and Mogotlhwane, O. (2012). Challenges facing SMEs in the adoption of ICT in $\mathrm{B} 2 \mathrm{~B}$ and $\mathrm{B} 2 \mathrm{C}$ E-commerce: $\mathrm{A}$ comparative case study of Botswana and Ghana. International Journal of Commerce and Management, 22(4), pp.272-285.

Awa, H. O., Ojiabo, O. U., and Emecheta, B. C. (2015). Integrating TAM, TPB and TOE frameworks and expanding their characteristic constructs for ecommerce adoption by SMEs. Journal of Science \& Technology Policy Management, 6(1), pp. 76-94.

Azam, M. S. (2007). Implementation of B2C E-Commerce in Bangladesh: The effects of buying culture and Einfrastructure. Advances in Global Business Research, 3(1), pp.55-81. 
Azam, M., and Quaddus, M. (2013). Examining the Influence of National Culture on Adoption and Use of Information and Communication Technology: A Study from Bangladesh's SME Perspective. The International Technology Management Review, 3(2), pp.116-126.

Bilbao-Osorio, B., Dutta, S., \& Lanvin, B. (2013). The global information technology report 2013. In World Economic Forum (1-383).

Blair, J., Czaja, R. F., and Blair, E. A. (2013). Designing surveys: $A$ guide to decisions and procedures. SAGE Publications, Incorporated.

Boateng, R., Heeks, R., Molla, A., and Hinson, R. (2008). E-commerce and socio-economic development: conceptualizing the link. Internet Research, 18(5), pp.562-594.

BTRC (2015). Bangladesh Internet Subscribers Statistic Report, Bangladesh Telecommunication Regulatory.

Chaffey, D. S. (2011). E-Business \& ECommerce Management. Prentice Hall, Upper Saddle River, New Jersey

Chong, W. K., Man, K. L., Chen, C., and Lai, H. Y. (2011). Design and Development of B2B e-Commerce Framework for Malaysian SMEs. In Proceeding of the International MultiConference of Engineers and Computer Scientists, II.

Cousins, K. C., and Robey, D. (2005). The social shaping of electronic metals exchanges: an institutional theory perspective. Information Technology and People, 18(3), pp.212-229.

Daniel, E., Wilson, H., and Myers, A. (2002). Adoption of E-Commerce by SMEs in the UK Towards a Stage Model. International Small Business Journal, 20(3), pp. 253-270.
Fowler, F. J. (1995). Improving survey questions: Design and evaluation. Sage Publications.

Gao, P. and Duncombe R. (2014). Introducing e-Business. e-Business: Organisation and Strategy Course Unit Handout, IDPM, University of Manchester, Manchester

Gibbs, J., Kraemer, K.L., and Dedrick, J. (2003). Environment and policy factors shaping global eCommerce diffusion: a cross-country comparison. The Information Society, 19, pp. 5-18. doi:10.1080/01972240309472, http://dx.doi.org/10.1080/0197224030 9472

Goode, S., and Stevens, K. (2000). An analysis of the business characteristics of adopters and nonadopters of World Wide Web technology. Information technology and Management, 1(1-2), pp.129-154.

Groves, R. M., Fowler Jr, F. J., Couper, M. P., Lepkowski, J. M., Singer, E., and Tourangeau, R. (2013). Survey methodology. John Wiley \& Sons.

Hair, J. F., Hult, G. T. M., Ringle, C., and Sarstedt, M. (2013a). A primer on partial least squares structural equation modeling (PLS-SEM). SAGE Publications, Incorporated.

Hair, J. F., Ringle, C. M., \& Sarstedt, M. (2013b). Partial Least Squares Structural Equation Modeling: Rigorous Applications, Better Results and Higher Acceptance. Long Range Planning, 1(46), pp. 1-12.

Hemple, P.S., and Kwong, Y.K. (2001). B2B eCommerce in emerging economies: i-metal.com's non-ferrous metals exchange in China. Journal of Strategic Information Systems, 10, pp. 335-355. doi:10.1016/S09638687(01)00058-0, http://dx.doi.org/10.1016/S09638687(01)00058-0 
Hoque, M. R., Ali, M. A., and Mahfuz, M. A. (2015). An Empirical Investigation on the Adoption of E-Commerce in Bangladesh. Asia Pacific Journal of Information Systems, 25(1), pp.1-24.

Hossain, M.A., Ali, M.A., Kibria, M.G., and Bhuiyan, M.N. (2013). A Survey of ECommerce of Bangladesh. International Journal of Science and Research, IJSR, India, pp.2319-7064.

Hossain, N. (2000). E-Commerce in Bangladesh: Status, potential and constraints. Institutional Reform and the Informal Sector, University of Maryland, College Park.

IDC (2014). Worldwide Digital Commerce Applications 2014-2018 Forecast and 2013 Vendor Shares, https://www.marketresearch.com/IDCv2477/Worldwide-Digital-CommerceApplications-Forecast-8389689/

Islam, M. M., Khan, A. M., and Islam, M. M. (2013). Textile Industries in Bangladesh and Challenges of Growth. Research Journal of Engineering Sciences, 2(2), pp.31-37.

ITU (2013). Measuring Information Society. Geneva: International Telecommunication Union (ITU), 2012.

Kapurubandara, M., and Lawson, R. (2006). Barriers to Adopting ICT and ecommerce with SMEs in developing countries: an Exploratory study in Sri Lanka. University of Western Sydney: Australia.

Kenneth, W., Rebecca, M. N., \& Eunice, A. (2012). Factors affecting adoption of electronic commerce among small medium enterprises in Kenya: Survey of tour and travel firms in Nairobi. International Journal of Business, Humanities and Technology, 2(4), pp.76-91.

Kuan, K. K., and Chau, P. Y. (2001). A perception-based model for EDI adoption in small businesses using a technology-organization-environment framework. Information \& management, 38(8), pp.507-521.

Kurnia, S., Karnali, R. J., and Rahim, M. M. (2015). A qualitative study of business-to-business electronic commerce adoption within the Indonesian grocery industry: A multitheory perspective. Information \& Management, 52(4), pp.518-536.

Lal, K. (2004). E-Commerce and export behavior: evidence from Indian firms. World Development, 32(3), pp.505517.

Lee, A. S. (1991). Integrating positivist and interpretive approaches to organizational research. Organization science, 2(4), pp.342-365.

Lee, C.-P., and Shim, J. P. (2007). An exploratory study of radio frequency identification (RFID) adoption in the healthcare industry. European Journal of Information Systems, 16(6), pp.712724. doi:10.1057/ palgrave.ejis.3000716

Lewis, P., Thornhill, A., and Saunders, M. (2007). Research methods for business students. Pearson Education: UK.

Licker, P.S. (1997), Management Information Systems: A Strategic Leadership Approach, The Dryden Press, Orlando, FL.

Lin, C., Huang, Y. A., and Burn, J. (2013). Realising B2B e-Commerce benefits: the link with IT maturity, evaluation practices, and B2BEC adoption readiness. European Journal of Information Systems, 16(6), pp.806819.

Lu, J., Yao, J. E., \& Yu, C. S. (2005). Personal innovativeness, social influences and adoption of wireless Internet services via mobile technology. The Journal of Strategic Information Systems, 14(3), pp. 245268. 
Molla, A., and Licker, P.S. (2005). Perceived E-Readiness factors in Ecommerce adoption: an empirical investigation in a developing country. International Journal of Electronic Commerce, 10, pp.83-110.

Montealegre, R. (1996). Implications of electronic commerce for managers in less-developed countries. Information Technology for Development, 7(3), pp.145-152.

Montealegre, R. (1999). A temporal model of institutional interventions for information technology adoption in less-developed countries. Journal of Management Information Systems, pp.207-232.

Moreton, R. (1995). Transforming the organization: the contribution of the information systems function. The Journal of Strategic Information Systems, 4(2), pp.149-163.

Morshed, M. M. (2007). A study on labour rights implementation in readymade garment (RMG) industry in Bangladesh: Bridging the gap between theory and practice. University of Wollongong Thesis Collection, 40.

Nielsen, J., Mathiassen, L., \& Newell, S. (2014). Theorization and translation in information technology institutionalization: Evidence from Danish home care. Mis Quarterly, 38(1), pp. 165-186.

Noor, M. A, and Arif, R. B. (2011). Adoption of B2B e-Commerce by the SMEs in Bangladesh. Innovative Systems Design and Engineering, 2(6), pp.4859 .

Olatokun, W., and Bankole, B. (2011). Factors Influencing Electronic Business Technologies Adoption and Use by Small and Medium Scale Enterprises (SMES) in a Nigerian Municipality. Journal of Internet
Banking and Commerce, 16(3), pp.126.

Oxley, J. E., and Yeung, B. (2001). Ecommerce readiness: institutional environment and international competitiveness. Journal of International Business Studies, pp.705-723.

Pham, L., Pham, L. N., \& Nguyen, D. T. (2011). Determinants of e-commerce adoption in Vietnamese small and medium sized enterprises. International Journal of Entrepreneurship, 15, pp. 45-72.

Pinsonneault, A., and Kraemer, K. L. (1993). Survey research methodology in management information systems: an assessment. Journal of management information systems, pp.75-105.

Rayhan, S. J., Saha, S., and Hassan, M. M (2014). Factors Affecting the Customer Buying Behavior in Relation to Readymade Garments in Bangladesh, International Research Journal of Marketing, Sciknow Publications Ltd.

Sahay, S., and Robey, D. (1996). Organizational context, social interpretation, and the implementation and consequences of geographic information systems. Accounting, Management and Information Technologies, 6(4), pp.255-282.

Saunders, M. N., Lewis, P., and Thornhill, A. (2011). Research methods for business students, 5/e. Pearson Education India.

Schonfeld, E. (2012). Forrester forecast: Online retail sales will grow to $\$ 250$ billion by 2014. Retrieved from TechCrunch: http://techcrunch. com/2010/03/08/forrester-forecastonlineretail-sales-will-grow-to-250billion-by-2014.

Seyal, A. H., Awais, M. M., Shamail, S., and Abbas, A. (2004). Determinants of electronic commerce in Pakistan: 
preliminary evidence from small and medium enterprises. Electronic Markets, 14(4), pp.372-387.

Tan, J., Tyler, K., and Manica, A. (2007). Business-to-business adoption of eCommerce in China. Information \& management, 44(3), pp.332-351.

Tarafdar, M., and Vaidya, S. D. (2006). Challenges in the adoption of $\mathrm{E}$ Commerce technologies in India: The role of organizational factors. International Journal of Information Management, 26(6), pp.428-441.

Tarofder, A. K., Marthandan, G., Mohan, A., and Tarofder, P. (2013). Web technology in supply chain: an empirical investigation. Business Process Management Journal, 19(3), pp.1-41.

Tran, Q., Zhang, C., Sun, H., and Huang, D. (2014). Initial Adoption Versus Institutionalization of E-Procurement in Construction Firms: An Empirical Investigation in Vietnam. Journal of Global Information Technology Management, 17(2), pp.91-116.

United Nations, (2012). World Population Prospects: The 2012 Revision. Retrieved from https://esa.un.org/unpd/wpp/publicatio ns/Files/WPP2012_HIGHLIGHTS.pdf

Vaithianathan, S. (2010). A review of eCommerce literature on India and research agenda for the future. Electronic Commerce Research, 10(1), pp.83-97.

Venkatesh, V. (2006). Where To Go From Here? Thoughts on Future Directions for Research on Individual - Level Technology Adoption with a Focus on Decision Making*. Decision Sciences, 37(4), pp.497-518.

WEF (2013). The Future of Government: Lessons from Around the World. Geneva: World Economic Forum. Available online
http://www3.weforum.org/docs/EU13/ WEF EU13 FutureofGovernment Report.pdf (Āccessed on 13/10/2014).

Wong, K. K. K. (2013). Partial Least Squares Structural Equation Modeling (PLS-SEM) Techniques Using SmartPLS. Marketing Bulletin, 24, pp.1-32.

Zikmund, W. G., Babin B. J., Carr J.C and Griffin M. (2010), Business Research Methods, 8th Edition, South-Western Cangage learning.

\section{About the Author}

Md. Rakibul Hoque is an Assistant Professor of Management Information Systems at University of Dhaka, Bangladesh. He received MSc degree from University of Manchester, UK. His research interests include technology adoption, eHealth and ICT4D. Mr. Hoque has published number of research articles in peer-reviewed academic journals, and has presented papers in international conferences. He had the opportunity to work in a number of research projects in Bangladesh, Australia, China and Saudi Arabia. Mr. Rakibul is the member of Association for Information Systems (AIS), UNESCO Open Educational Resources Community, Information Systems Audit and Control Association (ISACA), IEEE and Internet Society.

Richard Boateng is an Associate Professor in Information Systems at the University of Ghana Business School. He has an interest in developing, promoting and protecting ideas and concepts into sustainable projects of commercial value and development impacts. Richard is the Associate Editor of Information Technologies and International Development Journal and has published more than 30 articles in international journals, refereed conferences and book chapters. You can follow Richard on richboateng@ug.edu.gh. 